\title{
РОЛЬ ТА МІСЦЕ ОРГАНІЗАЦІЙНО-ПРАВОВОЇ БЕЗПЕКИ В СТРУКТУРІ ЕКОНОМІЧНОЇ БЕЗПЕКИ ПІДПРИЄМСТВА
}

\author{
Сьомич Микола Іванович \\ кандидат наук з державного управління, доцент \\ Полтавська державна аграрна академія (м. Полтава, Україна) \\ ORCID: 0000-0001-7049-9992 \\ Email: iriska7@ukr.net
}

\begin{abstract}
Узагальнено ключові риси поняття безпека. Ґрунтуючись на дослідженнях з безпекології, встановлено, що найбільш перспективною тріадою є така: «небезпека - загроза - безпека», а безпека має обов'язково відноситися до якогось об'єкта, функції або властивості якого піддаються впливу небезпек. Запропоновано множину «держава - регіон - підприємство» розширити додавщи поняття людина, що обумовлює зміст поняття «економічна безпека підприємства». Проаналізовано поняття «ризик», «загроза», «небезпека», «безпека», «виклик». Розглянуто зміст підходів в економічній безпекології: ресурсного (ресурсно-функиіонального), гармонізаційний, утилітарний або захисний, стійкісний. Надано авторське розуміння економічної безпеки підприємства. Окреслено предметну сферу дослідження організаційно-правової безпеки та ії відокремлення від економічної, яка полягає в детермінації сфер, в рамках яких відбуваються процеси, які характеризують досліджуване явище; в описі та класифікації загроз, які порушують протікання зазначених процесів у відповідних сфрерах; визначення наслідків, які можуть спричинити визначені загрози для протікання процесів в ході діяльності підприємства.
\end{abstract}

Ключові слова: економічна безпека, організаційно-правова безпека, безпекологія, загроза, небезпека, ризик, інтереси, цінності, потреби, нанорівень.

DOI: https://doi.org/10.32845/bsnau.2019.3.17

Постановка проблеми. Підвищення рівня складності зовнішнього середовища разом із збільшенням його варіативності, що проявляється у виникненні нових чинників впливу на діяльність підприємств, вимагає від суб'єктів господарювання посилення уваги до характеру перебігу подій та динаміки оточення, так як підприємство знаходиться в безпосередній залежності від дії цих чинників. Це обумовлено відкритістю підприємства як системи: із зовнішнього середовища підприємство отримує ресурси - природні, людські, інформаційні, нематеріальні, в зовнішнє середовище на виході підприємство реалізує продукцію, продукує відходи свого функціонування, генерує нові знання, створює власний інформаційний простір. Крім того підприємство знаходиться під постійним впливом механізмів, інститутів та інституцій різної природи, обсягів повноважень, характеру впливу, які приписують підприємству шляхи та способи здійснення господарської діяльності. Обсяг та якість ресурсів на вході залежить від численних параметрів зовнішнього середовища: типу соціальноекономічної системи, рідкості ресурсів, права власності на ресурси, характеру доступу до інформації, форми та ступеня державного втручання в національно економіку тощо. Зміст, характер та обсяг виходу підприємства першочергово залежить від вимог споживачів (в ринковій економіці), які формують попит у відповідному обсязі на продукцію означеного рівня якості. Створення та функціонування підприємства в рамках виробничого ланцюга має економічну природу. 3 іншого боку, будь-яка взаємодія підприємства як суб'єкта господарювання із зовнішнім середовищем на вході або виході підпадає під регулювання з боку інституцій та вплив інститутів у вигляді формальних норм. Від успішності протікання даної взаємодії залежить результативність діяльності підприємства. Поряд з економічною природою даних процесів внутрішнє перетворення на підприємстві в межах «чорного ящику» залежить від рівня організації діяльності, а всі взаємодії як всередині, так і зовні підприємства регулюється нормами

права. Будь-яка із цих сфер взаємовідносин разом із зовнішнім середовищем в цілому може виступати джерелом загроз, що обумовлює потребу у виокремленні організаційної та правової компоненти в загальній економічній безпеці як базовому понятті. Отже, виходячи з характеру функціонування підприємства у зовнішньому середовищі за умов існування або можливості виникнення загроз та небезпек логіка детермінації поняття «організаційно-правова безпека» передбачає аналіз етимології «безпека», розгляд основ та еволюції становлення безпекології в Україні, дослідження змісту економічної безпеки та підходів до ії розуміння, виокремлення організаційно-правових процесів які підпадають під загрози та небезпеки, і як результат - визначення змісту та наповнення організаційно-правової безпеки.

Аналіз останніх досліджень і публікацій. В основу дослідження покладено праці у галузі безпекології та управління економічною безпекою, де вагомі наукові результати отримано такими вченими як: Г. Атамановою, Д. Буркальцевою, Т. Васильцівим, В. Вахлаковою, В. Гейцем, С. Ілляшенком, О. Ляшенком, М. Караїм, М. Кизимом, А. Козаченко, Я. Маликом, О. Маслаком, О. Марченко, І. Мойсеєнко, Є. Овчаренком, О. Россошанською, С. Шкарлетом, Л. Шемаєвою, Л. Шульженко.

Мета статті. Мета дослідження полягає у визначенні ролі та місця організаційно-правової безпеки в структурі економічної безпеки підприємства.

Виклад основного матеріалу. Обґрунтування змісту організаційно-правової безпеки вимагає грунтовного дослідження феномену «безпеки», який виступає складним багатогранним поняттям, властивим різним об'єктам та досліджуваним рядом гуманітарних, точних та природничих наук.

На основі проведеного узагальнення сутності та змісту поняття «безпека» варто надати проміжні висновки.

По-перше, більшість дослідників вважають безпекою окремий стан відповідного суб'єкта, який характеризується 
множиною параметрів: відчуття впевненості, наявності захисту важливих інтересів, потреб або свобод, наявності динамічної рівноваги, збереження якісного визначення та вільного функціонування.

По-друге, серед численних визначень більшість в той або іншій формі включають поняття «загрози» або «небезпеки», що відображає стійку залежність між цими поняттями та досліджуваним. В цілому, більшість науковців сходяться до розуміння потреби детермінації безпеки через загрози та небезпеку.

По-третє, вимагає деякого уточнення «реальність» емпірична можливість існування - окремих визначень. Ряд дослідників наголошують на «стані відсутності загрози», що в реальній дійсності $€$ недосяжним, адже, як було розглянуто вище, підприємство як і будь-який інший суб'єкт (об'єкт) не знаходиться або функціонує у вакуумі - на нього впливає безліч чинників або факторів, які за окремих умов можуть набувати форми загроз або небезпек. Це вимагає уточнення поняття «безпека» з урахуванням постійної наявності загроз.

По-четверте, предметна сфрера дослідження безпеки фактично стосується різноманітних інтересів, цінностей і потреб, властивих окремому об'єкту. Це дозволяє розрізнити філософське, соціологічне, правове, політологічний, математичне, психологічне та економічне бачення безпеки. До вищезазначених необхідно додати кібернетичне, яке стосується характеру управління досліджуваним феноменом.

Узагальнюючи отримані результати визначимо: під поняттям «безпека» варто розуміти стан об'єкта, що характеризується сукупністю параметрів і здатністю ефективно протистояти загрозам, які характеризуються окремим рівнем вірогідності настання та ступенем впливу на об'єкт, спроможних порушити функціонування об'єкта, загальмувати або призупинити його розвиток, унеможливити досягнення його цілей, із відповідним рівнем суб'єктивності сприйняття з позиції управління.

Сучасні дослідження в галузі безпеки оформилися в ряд наукових течій, серед яких варто виокремити [1] безпекологію, безпекознавство, сек'юритологію (аналіз потреб та цінностей людини, що нею визначається, загрози існування, розвитку та нормальному життю людини та функціонуванню громадських організацій), севітологію (комплексна наука про безпечне функціонування людини, суспільства, держави та людства), екосесетейт (сукупність знань про умови безпечного функціонування соціально-економічних систем і способи їхнього забезпечення), екосесент (сукупність знань про економічну безпеку суб'єктів господарської діяльності), екосесед (сукупність знань про економічну безпеку закладів вищої освіти), екосерг (сукупність знань про економічну безпеку регіону).

В роботах Г. А. Атаманова, Є. І. Овчаренка, О. В. Росошанської, В. В. Вахлакової [1-4] надано узагальнення ключових положень безпекології, найбільш принциповим із яких в рамках дослідження варто визнати такі. Визнання об'єктами безпеки інтереси окремих суб'єктів, а не самих суб'єктів є дискусійним поняттям. Об'єкти на відміну від безпеки є об'єктивними існуючими частинами оточуючого світу, на якій має бути направлене дослідження, безпека виступає окремим станом як абстракція. Натомість загрози та небезпека є об'єктивною реальністю, вплив якої на об'єкт дослідження обумовлює виникнення феномену «безпека». Це доводить необхідність розгляду безпеки як реакції на небезпеку для окремого суб'єкта у відповідній площині дослідження. Це підтверджує визначення А. Уолферса [5], що безпека має суб'єктивну та об'єктивну компоненту: об'єктивна стосується реакції на загрози та небезпеки, а суб'єктивна - сприйняття безпеки суб'єктом дослідження. Отже, варто погодитися із дослідником [3], що найбільш перспективною тріадою в безпекології $€$ така: «небезпека - загроза - безпека», а безпека має обов'язково відноситися до якогось об'єкта, функції або властивості якого піддаються впливу небезпек. Вірним $€$ твердження, що оцінювання безпеки за допомогою різнопланових множин показників $€$ гносеологічного невиправданим, так як фактично дослідник намагається виміряти суб'єктивне сприйняття ним відповідного стану підприємства. 3 іншого боку, класичним $є$ твердження, що управляти можна лише тим, що можна розрахувати - це обумовлює об'єктивну потребу здійснення оцінювання, але його вектор має бути направлений на інші конкретні об'єкти оцінки: загрози, вірогідність їх виникнення, масштаб впливу на об'єкт дослідження, характер протікання процесів, які можуть виступати джерелом загроз та небезпек. Незважаючи на суб'єктивність природи безпеки існує реальна необхідність в розробці науково обірунтованих методів управління нею для забезпечення досягнення поставлених цілей, що і провокує масштабний розвиток теорій управління безпекою в різних галузях знань.

Предметна область дослідження охоплює питання причинно-наслідкових зв'язків економічної безпеки різних рівнів, закономірностей функціонування систем економічної безпеки, оцінювання рівнів та станів економічної безпеки суб'єктів, виявлення причин та чинників, які на неї впливають, розробки заходів забезпечення бажаного рівня. На нанорівні дослідження безпека розглядається як базова потреба відповідно піраміді А. Маслоу на рівень вище базових фізіологічних потреб. Незважаючи на нетотожність окремого індивідуума та суб'єкта господарювання саме відповідно цій ієрархії прослідковується критична важливість забезпечення належного рівня безпеки.

Узагальнюючі чисельні дослідження в галузі безпекології визначимо, що безпека $є$ виключно відповідним станом об'єкта, якого характеризує, а її сприйняття є суб'єктивним процесом. Крім того здатність досягати стану безпеки та можливість наукового обгрунтування даного процесу є дискусійним, що обумовлює необхідність розгляду досліджуваної категорії з епістемологічної точки зору лише через протиставлення небезпеці, яка детермінується множинами «загроз». На основі аналізу ряду понять «ризик», «загроза», «небезпека», «безпека», «виклик» встановлено, що принциповою різницею між «ризиком» та «загрозою» $є$ виключно негативний характер загрози, натомість «ризик» може розглядатися з позитивної точки зору як можливість; стан небезпеки є похідним від наявності загрози досліджуваному суб'єктом, а стан безпеки вважається бажаним, на досягнення якого мають бути спрямовані управлінські дії; розгляд дефініції «виклик» недоцільним, через його тотожність поняттю «загроза». Ключовий причинно-наслідковий зв'язок між дефрініціями варто представити таким чином: «загроза» - «небезпека» - «безпека», який виступає основою розробки управлінського інструментарію.

В рамках хронології економічної безпекології мікрорівня, яка виокремлює феноменологічний, дивергентний та конвергентно-седиментативний етапи, виник ряд напрямів розуміння економічної безпеки, кожного з яких або їх сукупно-

Вісник Сумського національного аграрного університету Серія «Економіка і менеджмент», випуск 3 (81), 2019 
сті дотримується більшість дослідників. Серед їх досить великої кількості в основу методології дослідження було покладено основи найбільш розвинутих та науково обгрунтованих. Утилітарний або захисний підхід розглядає стан захищеності суб'єкта, його потенціалу та інтересів від небажаних внутрішніх та зовнішніх загроз. В рамках ресурсного (ресурсно-функціонального) підходу розглядається їх використання для запобігання загрозам. Гармонізаційний підхід передбачає узгодження інтересів підприємства із суб'єктами зовнішнього середовища. Стійкісний підхід передбачає впровадження програми заходів для отримання фінансової стійкості в умовах наявності загроз. В цілому всю множину визначень та підходів можна об'єднати в такі групи розуміння безпеки як: стану захищеності як статистичного бачення, відсутності загроз і небезпек як апофатичного, системи заходів для створення безпечних умов як діяльнісного, дотримання параметрів як пасивного. Ключовим недоліком існуючих теорій та підходів щодо забезпечення безпеки підприємства $€$ неврахування вирішальної ролі людини, як об'єкта дослідження нанорівня, так як онтологічна природа безпеки пов'язана із поняттями: потреби, інтереси та цінності, які властиві як підприємству, так і людини. Відповідно множину «держава - регіон - підприємство» варто розширити додавши поняття людина, що обумовлює зміст поняття «економічна безпека підприємства». Таким чином, «економічна безпека підприємства» як детермінований стан, з гносеологічної точки зору, розкривається через включення в його структуру на мікрорівні людини як суб'єкта нанорівня, де наріжним каменем виступає тріада «потреби - інтереси - цінності» підприємства та людини, задоволення, реалізація та збереження яких на достатньому рівні виступає цільовим орієнтиром.

Отже, на основі проведеного дослідження запропонуємо власне розуміння змісту поняття «економічна безпека підприємства». По-перше, воно передбачає стійкість до загроз як існуючих, так і можливих - тобто створення властивості підприємства як системи підтримувати власне нормальне функціонування за умови несприятливого впливу загроз як специфічний «запас міцності», формування та розвиток якого вимагає виокремлення ресурсів. По-друге, недостатність уваги з боку дослідників до найнижчого рівня аналізу економічної безпеки - нанорівня - який опосередковує інтереси, потреби та цінності окремих людей, значно звужує горизонт отримання наукових результатів. Це вимагає зміни фокусу в аналізі підприємства до більш глибинного визначення ролі кадрів та всіх інших персоналій, зацікавлених в роботі підприємства. Це обумовлює розширення об'єктного складу до такого вигляду: «держава - регіон - підприємство - людина», де об'єднуючими всі ці рівні виступають «потреби», «інтереси» та «цінності» (в економічному розрізі цих категорій), захист яких від загроз є основною функцією економічної безпеки всіх цих рівнів. Поєднання захисту інтересів, цінностей та потреб із забезпеченням нормального функціонування підприємства в умовах впливу загроз представляє суб'єктно-об'єктний характер економічної безпеки, метою якої $є$ створення стану стійкості, як відображення наявності зазначеної властивості. Детермінація стійкості - сукупність параметрів із відповідними значеннями, незмінність яких забезпечує стабільність підприємства. Розширення меж гармонізаційного підходу передбачає включення до аналізу захисту інтересів, потреб та цінностей суб'єктів як зовнішнього, так і внутрішнього середо- вища. Найвищим рівнем реалізації функції безпеки є забезпечення розвитку підприємства.

Організаційна діяльність відіграє важливу роль в забезпечення функціонування підприємства на бажаному рівні: управління, невід'ємною складовою якого є реалізація функції організації, має забезпечувати доведення підприємства до реалізації поставлених цілей, а організація як феномен в рамках теорії систем для підприємства відіграє вирішальну роль збереження його цілісності як єдиного учасника товарно-грошових відносин. Керівництво підприємства зацікавлене у стабільний безперебійні діяльності, без виникнення внутрішніх ризиків та загроз поточному функціонуванню.

Відповідно безпека організаційної діяльності підприємства передбачає такий стан налагодження процесів сфери організації діяльності працівників, делегування повноважень, ефрективності організаційної структури та ієрархії влади за підтримки належного рівня вмотивованості, за яким існування реальних або потенційних керованих загроз здійсненню основної та всіх інших видів діяльності не спричиняє невідворотного впливу та не зупиняє діяльність.

Окреслення предметної сфрери дослідження організаційно-правової безпеки та відокремлення її від економічної полягає в детермінації сфер, в рамках яких відбуваються процеси, які характеризують досліджуване явище; в описі та класифікації загроз, які порушують протікання зазначених процесів у відповідних сферах; визначення наслідків, які можуть спричинити визначені загрози для протікання процесів в ході діяльності підприємства. Виходячи із окресленою предметної сфери розробляються та обгрунтовуються заходи та механізми забезпечення бажаного рівня безпеки з позиції суб'єкта управління.

В історії людства одним із найбільш вагомих є право власності на землю, майно, засоби виробництва та будь-які інші цінності. За декілька тисячоліть ці права відчутно трансформувалися. Зараз декларативно недоторканим вважається право приватної власності, яке опосередковано виступає головною передумовою привласнення результатів комерційної діяльності, в основі якої знаходиться виробництво, в яке залучено майно власника. Якщо умовно розділити процеси створення доданої вартості та питання присвоєння результатів, «водорозділ» економічної безпеки та організаційно-правової стає очевидним, але на практиці це неможливо. Будь-яке виробництво в будь-якій цивілізованій країні має вичерпний перелік організаційно-правових форм господарювання, в рамках яких може здійснюватися підприємницька діяльність. Тобто виробництво таким чином «уміщується» в законодавчо-дозволену та регламентовану форму, яка, перш за все, відображає характер розподілу прибутку в залежності від типу власності, захищає права власника на отримання прибутку або його долі, захищає майно власника так переписує взаємодію із всіма сторонами, як зовнішніми контрагентами так і внутрішніми працівниками. У сфері організаційно-правової безпеки акцент змішується з безпосередньо виробництва, та питань пов'язаних з ним, до взаємовідносин щодо забезпечення нормального протікання процесу виробництва. В даному випадку, об'єктом, який потребує захисту, є конкретний суб'єкт із відповідною організаційно-правовою формою господарювання, діяльність якого конкретно та однозначно детермінованим законодавством. Очевидно, що економічна та організаційна безпеки $є$ нероздільними, адже обидві стосуються суб'єкта господарювання, але перша 
- з позиції переважно виробництва, а друга - здійснення підприємницької діяльності в цілому.

Для подальшої детермінації різниці між цими категоріями варто розглянути типи загроз та наслідки їх впливу. В роботі [6] надано ємний перелік внутрішніх і зовнішніх загроз економічній безпеці. Серед зовнішніх визначимо: крадіжки, шпигунство, недобросовісну конкуренцію, протизаконні фрінансові операції. Вплив цих загроз стосується фінансів підприємства, порушення нормального функціонування яких може призвести до значних втрат через несвоєчасність проведення необхідних розрахунків. Наслідки можуть мати як глобальний, так і локальний характер. Для суб'єктів аграрного бізнесу додатковими виступають загрози, пов'язані із природним середовищем. Це стосується несприятливих погодних умов, нанесення шкоди рослинним насадженням 3 боку шкідників, диких тварин, забруднення джерел води тощо. 3 боку постачальників це стосується неякісного насіннєвого матеріалу або не своєчасності його поставки, неукомплектованості, неякісних мінеральних добрив тощо. Все це призводить до порушення виробничого процесу, негативно впливає на результати, що обумовлює погіршення підсумкових фінансових результатів. Загрози з боку природного середовища властиві саме сфері економічної безпеки, а загрози взаємодії із постачальниками відносяться до сфери організаційно-правової безпеки, так як торкаються форм регулювання цих правовідносин. Актуальними для суб'єктів аграр- ного бізнесу є макроекономічні загрози, які торкаються коливання цін на готову продукцію, на паливно-мастильні матеріали, на послуги транспортування та логістики, впливають на собівартість продукції або ціну реалізації, обумовлюючи відповідний рівень прибутку. Ці загрози торкається економічної безпеки. 3 іншого боку, при укладанні контрактів відносно реалізації готової продукції суб'єкти аграрного бізнесу можуть стикатися із недоброчесним поводженням зовнішніх контрагентів - ці загрози відносяться вже до організаційно-правової безпеки, але одночасно торкається і економічної. Принциповою різницею відносно розділення цих двох понять є обов'язковість присутності у сфері організаційно-правової безпеки суб'єкта взаємодії, відносини з яким можуть виступати джерелом потенційних загроз, що дозволяє розглядати як ключову в методології управління організаційно-правовою безпекою теорію зацікавлених сторін.

Висновки. На основі здійсненого узагальнення наявних підходів до розуміння поняття «безпека», «економічна безпека» та їх організаційно-правових аспектів запропоновано розуміння організаційно-правової безпеки суб'єктів аграрного бізнесу як відповідного стану, в якому підприємство здатне фуннцціонувати як самостійний суб'єкт господарювання, зберігати свою юридичну та майнову цілісність, здійснювати діяльність, яка відрізняється від основної (фінансову та інвестиційну), входити до об'єднань та здійснювати внутрішнє управління.

\section{Список використаної літератури:}

1. Вахлакова В. В. Економічна безпекологія: становлення науки. Problems of Economy, 2017, 1. с. 290-296.

2. Атаманов Г. А. Основные виды безопасности антропных систем и их иерархия. Проблемы безопасности. 2010. № 2 (10). URL: http://www.naukaxxi.ru/materials/257

3. Овчаренко $€$. І. Сучасна економічна безпекологія: основні онтологічні протиріччя та напрями їх вирішення. Бізнес Інформ. 2016. № 11. С. 8-14.

4. Россошанська О. В. Сутність економічної безпеки суб'єктів господарювання як сфери економічної науки. Управління проектами та розвиток виробництва: Зб.наук.пр. Луганськ: вид-во СНУ ім. В.Даля, 2011. № 2 (38). С. 161-166.

5. Wolfers A. A. Discord and Collaboration. Essay of International Politics. Foreword by Reinhold Niebuhr. Baltimore: The Johns Hopkins Press, 1962. 24 p.

6. Іванків О. Діагностика загрози економічній безпеці підприємства й напрями їх нівелювання в умовах євроінтеграційних процесів. Economic journal of Lesia Ukrainka Eastern European National University. 2016. Т. 1. №. 5. C. 40-45.

Syomych M. I., PhD in Public Administration, Associate Professor, Poltava State Agrarian Academy (Poltava, Ukraine) The role and place of organizational and legal security in the enterprise economic security structure.

The article is devoted to determining the role and place of organizational and legal security in the structure of an enterprise economic security. The peculiarities of the enterprise functioning in the external environment under the influence of numerous threats and dangers are investigated. The key features of the security concept are summarized: it acts as a separate state for entities characterized by many parameters; security is closely linked to concepts such as «threat» and "danger»; the enterprise operates under conditions of constant presence of threats; the subject area of security research is the variety of interests, values and needs peculiar to the individual subject. Based on security studies, it has been established that the most promising triad is: «danger - threat - security", and security must necessarily relate to any object whose function or properties are exposed to the danger. It is proposed to expand the set of "state - region - enterprise» by adding the concept of a person, which determines the meaning of the concept "economic security of the enterprise». Based on the analysis of a number of concepts of "risk», "threat», "danger», "security», "challenge» it is established that the fundamental difference between «risk» and "threat» is exclusively negative nature of the threat, instead «risk» can be considered with a positive point of view as an opportunity; the state of danger is derived from the threat being investigated by the subject, and the state of security is considered desirable, to which management actions should be directed; consideration of the definition of «challenge» is impractical, because of its identity to the concept of «threat». The content of approaches in economic security is considered: resource (resource-functional), harmonization, utilitarian or protective, sustainable. The author's understanding of the enterprise economic security is provided. The subject area of the study of organizational and legal security and its separation from the economic is outlined, which is the determination of the spheres within which the processes that characterize the phenomenon under study are outlined; in the description and classification of threats that disrupt the processes in these areas; 
identification of the consequences that can cause certain threats to the processes in the course of the enterprise activity.

Key words: economic security, organizational and legal security, security, threat, danger, risk, interests, values, needs, nanoscale.

Дата надходження до редакції: 20.07.2019 р. 